\title{
POLEMIK PEMBERIAN HARTA WARIS MELALUI WASIAT KEPADA ANAK ANGKAT
}

\author{
Habiburrahman \\ Mahkamah Agung Republik Indonesia \\ E-Mail: variaperadilan@mahkamagagung.go.ig
}

\begin{abstract}
This paper describes the polemic of the distribution of waris for foster child in the study of Islamic law and the laws and regulations in Indonesia. The distribution of estate to foster child was regulated in article 209 in the Compilation of Islamic Law $(\mathrm{KHI})$. Thus, this is a signal that the influence of customary law and Western law had entered in KHI . Therefore, by this paper, Author would like to emphasize that the distribution of waris to the foster child by using the concept of wasiat wajibah in $\mathrm{KHI}$ is wrong. It is not based on the shari'ah (qath'iy al-dilalah), but rather based on logic of the law and humanitarian considerations, and it is zhanniy al-dilâlah. Thus, author sure that the distribution of waris by one third (1/3) of estate to the foster child by using the concept of wasiat wajibah is an erroneous ijtihad, cotradiction with the texts, and could be detrimental to the main heirs.
\end{abstract}

\begin{abstract}
Abstrak
Tulisan ini menjelaskan tentang polemik pemberian harta waris kepada anak angkat dalam diskursus ilmu hukum Islam dan peraturan perundang-undangan di Indonesia. Ketentuan hukum pemberian harta warisan kepada anak angkat sebagaimana diatur dalam Pasal 209 Kompilasi Hukum Islam (KHI) merupakan fakta yuridis masuknya pengaruh hukum Adat dan hukum Barat ke dalam KHI. Oleh karena itu, dalam tulisan ini, penulis ingin menegaskan bahwa pemberian harta warisan kepada anak angkat dengan menggunakan konsep wasiat wajibah ke dalam KHI, pada umumnya bukan didasarkan kepada landasan syari'at (qath'iy al-dilâlah), tetapi lebih didasarkan kepada logika hukum dan pertimbangan kemanusiaan ahli waris untuk memberikan sebagian harta waris kepada saudara atau anak angkat, meski secara syar'i hal tersebut termasuk zhanniy al-dilâlah. Sehingga pemberian harta waris sebesar $1 / 3$ dari harta waris kepada anak angkat dengan menyandarkan hukum kepada wasiat wajibah, merupakan ijtihad yang keliru, bertentangan dengan nash, dan dapat merugikan ahli waris utama.
\end{abstract}

Kata Kunci:

Waris, Harta Waris, Anak Angkat, dan Wasiat Wajibah.

\section{A. Pendahuluan}

Indonesia mayoritas penduduknya menganut agama Islam dalam komunitas kehidupan berbangsa dan bernegara secara konstitusional tidak mengklaim mazhab tertentu dan fenomena ini perlu disyukuri karena memberikan peluang perkembangan daya ijtihad, khususnya pemeluk agama Islam di Indonesia. Kalangan cendekiawan muslim Indonesia sangat memberikan apresiasi yang positif jasa-jasa para ulama mujtahid terdahulu yang telah melakukan studi kritis ten- tang nilai-nilai keislaman, misalnya Ibnu Mas'ud, Ibnu 'Abbas, Ibnu Zubayr, Imam Empat (Hanafi, Mâliki, Syafi'i, dan Ahmad), Daud alDhahiri adalah pionir-pionir gerak dinamis daya ijtihad yang patut diikuti jejaknya.

Kaitannya dengan hukum waris, khususnya waris yang berdasarkan hasil ijtihad para ulama Indonesia yang menjadi topik dalam penelitian ini, yaitu rekonstruksi hukum kewarisan Islam di Indonesia, merupakan salah satu dinamika hukum Islam. Perbedaan pendapat di kalangan ahli hukum Islam adalah 
sesuatu yang menarik untuk dikritisi, baik hasil ijtihadnya maupun metode pendekatannya seiring dengan perkembangan epistemologi studi keislaman dalam konteks kekinian. Misalnya mengenai hukum kewarisan $\mathrm{KHI}$, dalam pelaksanaannya telah tertuang dalam putusan Pengadilan Agama, Pengadilan Tinggi Agama, dan Mahkamah Agung RI selain ditemukan pula disparitas putusan untuk suatu kasus yang sama, ketidakpastian hukum, yang dianggap masih menyimpang dari ketentuan nash al-Quran dan Sunnah, serta menyimpang dari tujuan disyariatkannya hukum kewarisan Islam.

Kemudian dilihat dari aspek pengembangan ilmu hukum, mayoritas penduduk Indonesia beragama Islam. Hal ini tentunya berpengaruh terhadap dinamika hukum waris Islam dan aplikasinya di Pengadilan Agama, Pengadilan Tinggi Agama, dan Mahkamah Agung Republik Indonesia. Boleh jadi putusan-putusan hakim agama di pengadilan juga menarik untuk dikaji lebih dalam melalui pendekatan ilmiah dengan tanpa mengabaikan dinamika sosial dan budaya Indonesia saat ini. Salah satu obyek hukum yang menarik untuk dikaji adalah polemik pemberian harta waris kepada angkat dalam diskursus ilmu hukum Islam dan peraturan perundang-undangan di Indonesia.

\section{B. Perkembangan Teori-teori Hukum Wa- ris Islam di Indonesia}

Perkembangan teori hukum waris Islam di Indonesia sedikit banyak dipengaruhi oleh konsep wasiat wajibah yang diadopsi dari hukum keluarga Islam di Mesir. Teori ini muncul sebagai tesa, antitesa, dan sintesa dari teoriteori berlakunya hukum Islam di Indonesia, yang berujung pada dimasukkannya ketentuan waris bagi anak angkat dalam $\mathrm{KHI}$ dan pemberian harta waris dengan wasiat wajibah untuk anak yang murtad. Teori-teori hukum yang dimaksud antara lain:

Pertama, teori receptie in complexue diperkenalkan oleh Lodewijk Willem Christian van den Berg (1845-1927 M), yang menyatakan bahwa bagi orang Islam berlaku penuh hukum Islam, sebab ia telah memeluk agama Islam walaupun dalam pelaksanaannya terdapat penyimpangan-penyimpangan.
Menurut van den Berg, hukum Islam telah berlaku pada masyarakat asli Indonesia sejak $1885 \mathrm{M}$ yang diperkuat dengan Regeering Reglement, dan hukum perkawinan dan kewarisan Islam dalam Compendium Freijer tahun 1706 M. ${ }^{1}$ Inti dari teori receptie in complexu dari Christian van den Berg menegaskan bahwa hukum yang berlaku bagi suatu masyarakat adalah hukum dari agama yang dianutnya. Atau secara ringkas dan sederhana disebut bahwa setiap orang beragama tunduk kepada hukum dari agama yang dianutnya. ${ }^{2}$

Kedua, teori Receptie yang diperkenalkan oleh Christian Snouck Hugronye (1857$1936 \mathrm{M}$ ) yang kemudian dikembangkan oleh C. van Vollenhoven dan Ter Haar. Snouck Hugronye sendiri dikenal sebagai penasehat pemerintah Hindia Belanda tentang soal-soal Islam dan anak negeri tahun $1898 \mathrm{M}$. Ia pernah pergi ke Mekkah dan belajar tentang Islam hingga berganti nama menjadi Abdul Gaffar. Keahliannya dalam mempelajari hukum Islam dan hukum adat diwujudkan dalam karyanya De Atjehers dan De Gojoand. ${ }^{3}$ Dalam pokok-pokok teori receptie, Hugronye menyebutkan bahwa bagi rakyat pribumi pada dasarnya berlaku hukum adat, dan hukum Islam akan berlaku apabila normanorma hukum Islam telah diterima/diserap oleh masyarakat hukum Adat. Teori ini dikembangkan oleh Vollenhoven dan Ter Haar semata-mata untuk kepentingan munculnya Pan-Islamisme di Indonesia serta untuk memperkokoh penjajahan di Indonesia.

Ketiga, teori Receptie Exit dikemukakan oleh Hazairin yang memberikan pertentangan terhadap teori receptienya Snouck Hugronye. Menurut Hazairin, hukum Islam adalah hukum yang mandiri dan lepas dari pengaruh hukum lainnya, sebagaimana ia menghubungkannya dengan sumber dan me-

${ }^{1}$ A. Hanafi, Teologi Islam (Jakarta: Pustaka AlHusna. 1987), hlm. 138 dan Taufiq Idris, Aliran-aliran Populer dalam Teologi Islam (Surabaya: Bina Ilmu. 1980), hlm. 18

${ }^{2}$ Aqib Suminto, Politik Islam Hindia Belanda (Jakarta: LP3ES. 1985), hlm. 9.

${ }^{3}$ Ibid. hlm. 120-122. 
tode hukum Islam. ${ }^{4}$ Dan ketika Indonesia memasuki masa kemerdekaannya, hukum Islam mewarnai sistem hukum nasional dan tatanan kehidupan masyarakat Islam di seluruh Indonesia. Alasan yang dikemukakan oleh Hazairin didasarkan pada pembukaan Undang-Undang Dasar 1945 bahwa "Atas berkat rahmat Allah Yang Maha Kuasa dan didorong oleh keinginan yang luhur dan bebas, maka dengan ini bangsa Indonesia menyatakan kemerdekaannya." Kemudian dipertegas lagi dalam alinea IV Pembukaan Undang-Undang Dasar 1945: "Negara berdasarkan Ketuhanan Yang Maha Esa." Merupakan kompromi untuk memberlakukan syari'at Islam dalam konstitusi negara. ${ }^{5}$ Selain itu, Batang Tubuh Undang-Undang Dasar 1945 Pasal 29 ayat (1-2) merupakan jaminan bagi berlangsungnya penerapan hukum Islam di Indonesia, dan dengan sendirinya teori receptie Snouck Hugronye tertolak. Dalam perkembangan kemudian adanya Departemen Agama yang berdiri pada tanggal 3 Januari 1946 beserta pranatapranata sosial, budaya, politik, dan hukum yang bercorak Islam merupakan implementasi penerapan syari'ah Islam di Indonesia.

Keempat, teori Receptie a Contrario yang dikembangkan oleh Sayuti Thalib dan juga merupakan pengembangan dari teori Receptie Exit Hazairin. Dalam tulisannya, Receptie a Contrario: Hubungan Hukum Adat dengan Hukum Islam, hasil penelitian Sayuti Thalib menemukan kesimpulan mengenai masalah perkawinan dan waris bahwa: (a) bagi orang Islam berlaku hukum Islam; (b) hukum Islam berlaku sesuai dengan cita hukum, cita moral dan bathin umat Islam; dan (c) hukum Adat berlaku, jika tidak bertentangan dengan ajaran Islam. ${ }^{6}$ Berdasarkan rumusan tersebut,

${ }^{4}$ Penentangan Hazairin terhadap teori Receptienya Snouck Hugronye disebut dengan "Teori Iblis" karena asumsi-asumsi Snouck Hugronye sama sekali tidak memiliki dasar hukum atau logika yang murni, bahkan secara ideologis bertentangan dengan kemauan syari'at Islam dalam al-Quran dan Sunnah.

${ }^{5}$ Muhammad Daud Ali, Hukum Islam: Pengadilan Agama dan Masalahnya (Bandung: Rosdakarya. 1991), hlm. 74 .

${ }^{6}$ Ichtiyanto, Pengembangan Teori Berlakunya Hukum Islam di Indonesia (Bandung: Rosda Karya. 1991), hlm. 131-133.
Sayuti Thalib berpendapat bahwa teori Receptie Hugronye sebagai "teori iblis", karenanya bukan berasal dari kemauan hukum syari'at serta akal sehal. Selain itu, ia juga menegaskan bahwa hukum Islam merupakan hukum yang berdiri sendiri dan tidak dapat ditundukkan kepada hukum Adat, sehingga hukum Islamlah yang mewarnai hukum Adat.

Formulasi ketentuan ahli waris pengganti yang bukan ahli waris diposisikan menjadi ahli waris pengganti dalam Kompilasi Hukum Islam (KHI). Demikian pula dengan ketentuan waris bagi anak angkat dan ahli waris beda agama dengan formulasi wasiat wajibah dapat masuk ke dalam KHI. Dalam konteks ini, sebagian pendapat mengatakan bahwa untuk menjamin proses penegakan hukum waris Islam di kalangan umat muslim, teori mashlahah dan maqashid al-syari'ah sebagai landasan teoritis untuk menjelaskan rekonstruksi hukum waris Islam di Indonesia.

Teori mashlahah yang pertama dikemukakan oleh Imam al-Syatibi, yang dikenal sebagai salah seorang pemikir hukum Islam yang banyak menjelaskan teori mashlahah dalam karyanya, al-muwâfaqat, melalui konsep tujuan hukum syara' (maqâshid al-syari'ah). Perumusan tujuan syari'at Islam bertujuan untuk mewujudkan kemaslahatan umum (mashlahah al-'ammah) dengan cara menjadikan aturan hukum syari'ah yang paling utama dan sekaligus menjadi shalihah li kulli zaman wa makân (kompatibel dengan kebutuhan ruang dan waktunya) untuk sebuah kehidupan manusia yang adil, bermartabat dan bermaslahat.

Berdasarkan teori tersebut, pelaksanaan hukum waris Islam di Indonesia hendaknya diaplikasikan sesuai dengan prinsip-prinsip, asas-asas, dan tujuan hukum syara'. Imam alSyatibi memberikan rambu-rambu untuk mencapai tujuan-tujuan syari'at yang bersifat dharuriyyah, hajjiyyah, dan tahsiniyyah dan berisikan lima asas hukum syara' yakni: (a) memelihara agama/hifzh al-dîn; (b) memelihara jiwa/hifzh al-nafs; (c) memelihara keturunan/hifzh al-nasl: (d) memelihara akal/hifzh 
al-aql; dan (e) memelihara harta/hifzh al-mâl. ${ }^{7}$ Sepanjang eksistensi Peradilan Agama tersebut mampu menjamin bagi tercapainya tujuan-tujuan hukum syara' maka kemaslahatan menjadi tujuan akhir. Teori mashlahah yang diperkenalkan al-Syatibi dalam konsep maqâshid al-syari'ah ini tampaknya masih relevan untuk menjawab segala persoalan hukum di masa depan, termasuk pula masalah pemberian hak waris pengganti dengan wasiat wajibah kepada anak angkat sebagaimana diatur dalam KHI.

\section{Posisi Anak Angkat dalam Hukum Waris Islam di Indonesia}

Anak angkat mendapat kedudukan istimewa di Indonesia, kedudukannya dipersamakan dengan anak kandung dalam suatu keluarga, sehingga apabila orang tua angkatnya meninggal dunia dia dapat menjadi ahli waris satu-satunya, atau paling tidak dapat me-mahjub-kan saudara kandung pewaris. Hal ini dapat dilihat dalam yurisprudensi Pengadilan Negeri dan Mahkamah Agung Republik Indonesia.

Mendudukkan anak angkat menjadi ahli waris pengganti seperti demikian, dalam Islam dilarang berdasarkan teguran langsung Allah SWT atas pengangkatan anak (tabanny) oleh Rasulullah SAW terhadap Zayd bin Haritsah. ${ }^{8}$ Dalam Islam anak angkat bukanlah ahli waris. Namun tidak banyak diperoleh informasi tentang bagaimana $\mathrm{KHI}$ memberi kedudukan istimewa dengan pemberian wasiat wajibah kepada anak angkat sebanyak-banyaknya $1 / 3$ dari harta warisan orang tua angkatnya. ${ }^{9}$

Dikatakan istimewa, karena kalangan ulama ahli tafsir, hadits, dan fikih tampaknya tidak memberi kedudukan dan pemberian "wasiat wajibah" seperti itu. Apakah anak angkat termasuk kesepakatan ulama Indonesia, ataukah bentuk pemaksaan oleh pejabat pada Mahkamah Agung dan Departemen Agama sebagaimana masuknya ahli waris pengganti di atas? Atau apakah Ketua Tim Pe-

${ }^{7}$ Al-Syâthibi, al-Muawâfaqat fi Ushûl al-Syari'ah (Beirut: Dâr al-Kutub al-Ilmiyyah. t.th.), juz II, hlm. 7.

${ }^{8}$ Q.S. Al-Ahzab: 4-5.

${ }^{9}$ Pasal 209 ayat (1) dan (2) Kompilasi Hukum Islam. rumus $\mathrm{KHI}$ tidak mengomentari masalah ahli waris pengganti saja, ataukah lebih luas lagi termasuk anak angkat? Dan apakah Hakim Tinggi dan Ketua Pengadilan Agama yang mendengar langsung di dalam kelas Pendidikan Hakim Senior Angkatan II Tahun 1992 M di Tugu Bogor sekalipun juga tidak menginformasikan lebih jauh mengenai hal tersebut?.

Kedudukan anak angkat lebih tegas lagi diatur setelah lahirnya Undang-Undang Nomor 3 Tahun 2006 tentang Perubahan atas Undang-Undang Nomor 7 Tahun 1989 tentang Peradilan Agama. Dalam UU tersebut dinyatakan bahwa penetapan asal-usul seorang anak dan penetapan pengangkatan anak berdasarkan hukum Islam. ${ }^{10}$ Pengukuhan anak angkat berdasar hukum Islam secara akademis telah dikomentari oleh pakar-pakar hukum Islam di Indonesia dan membatasinya dengan "anak" sebatas pemeliharaan, pendidikan, pengayoman, dan hak-hak anak pada umumnya, tidak boleh memperlakukan atau mendudukkannya seperti anak sendiri.

Dengan demikian tidak tampak adanya pihak yang menentang kedudukan anak angkat dalam KHI. Peneliti berasumsi dalam posisi inilah teori receptie a contrario dapat memberikan contoh bahwa hukum Adat telah diterima oleh hukum Islam. Tetapi, ketentuan wasiat wajibah bagi anak angkat $1 / 3$ dari harta warisan pada awalnya banyak ditentang oleh ahli waris yang merasa dirugikan, yang mana hak mereka menjadi tergantikan dengan adanya pengakuan kedudukan anak angkat menjadi ahli waris pengganti. Padahal pengharaman segala tindakan yang dapat menimbulkan kerugian bagi ahli waris mutlak telah ditegaskan dalam sabda Rasulullah SAW yang berbunyi:

$$
\text { حرمة الأضرار بالورثة: يحرم أن يقف الشخص وقفا يضارّبه }
$$

Tidak boleh mendatangkan kemudharatan bagi ahli waris. Haram mewakafkan harta yang dapat menimbulkan kerugian bagi ahli waris, sebagaimana hadits Rasulullah SAW:

\footnotetext{
${ }^{10}$ Penjelasan Pasal 49 Huruf a angka 20 Undangundang Nomor 3 Tahun 2006.
} 
tidak memudharatkan dan tidak dimudharatkan.

Hadits tersebut di atas telah dikukuhkan oleh ulama Ushûl Fikih sebagai salah satu kaidah hukum Islam yang berbunyi: لاضرر و لا ضرار (tidak madharat dan memadharatkan).. Dengan kata lain, kalangan ulama Ushûl memandang bahwa memposisikan anak angkat sebagai ahli waris pengganti tentu dianggap keliru karena cenderung memadharatkan dan/atau merugikan ahli waris mutlak yang senasab. Alasan yang paling normatif adalah memposisikan anak angkat sebagai ahli waris pengganti jelas bertentangan dengan alQuran dan Sunnah.

Sedangkan Yurisprudensi di Pengadilan Agama juga menunjukkan bahwa masih terdapat disparitas bagian wasiat wajibah bagi anak angkat. Sebagian hakim Pengadilan Agama tidak mau repot secara serta merta memberikan hak waris bagi anak angkat berdasarkan wasiat wajibah sebesar $1 / 3$ dari harta warisan orang tua angkatnya, tanpa mempertimbangkan apakah pemberian maksimal tersebut telah merampas hak-hak ahli waris ataukah telah adil dan bijaksana. ${ }^{12}$ Sedangkan sebagian hakim lainnya memberi bagian wasiat wajibah tidak melebihi bagian terkecil dari ahli waris.

Berkenaan dengan hal tersebut di atas, tentu cara yang kedua ini dianggap amat pelik dan rumit, karena harus dihitung lebih dahulu bagian semua pihak ahli waris dan sekaligus bagian anak angkat. Jika ternyata bagian untuk anak angkat masih melebihi dari bagian terkecil di antara ahli waris, maka perlu dilakukan penghitungan ulang. Hakim yang senang dengan hitung-menghitung tidak banyak, karena harus menguasai ilmu hitung. Pada gilirannya, pola pikir model yang kedua dianggap lebih sesuai dengan pesan yang terkandung di dalam surat al-Ahzab tersebut, yaitu larangan memberlakukan anak angkat seperti anak sendiri.

${ }^{11}$ Rachmat Syafe'I, IImu Ushûl Fiqih Untuk UIN, STAIN, PTAIS (Bandung: Pustaka Setia. 2007), cet. III, hlm. 257.

${ }^{12}$ Q.S. An-Nahl: 90.
Selanjutnya, cara lain yang ditempuh untuk memberikan harta warisan kepada anak angkat adalah dengan cara adopsi. Adopsi ialah pengambilan anak laki-laki. ${ }^{13}$ Hukum adopsi berlaku di kalangan orang Cina, yang dimaksudkan suatu hak untuk mengambil seorang pemuda menjadi keturunan yang sah, disertai dengan pengakuan dari pihak yang mengambil untuk memperkenalkan nama sukunya (Sengnaam). ${ }^{14}$ Namun, masalah hak waris bagi anak adopsi dalam konteks hukum Islam di Indonesia telah diatur dalam Kompilasi Hukum Islam (KHI) sebagaimana pula ketentuan mengenai wasiat wajibah.

Namun ada persoalan yang menarik untuk dicermati yaitu adanya yurisprudensi dalam Putusan Mahkamah Agung Nomor: 245 K/AG/1997 mengenai Hak Mewaris Anak Angkat. Ketentuan Pasal $209 \mathrm{KHI}$ bahwa seorang anak angkat berhak maksimal $1 / 3$ bagian harta peninggalan orang tua angkatnya sebagai suatu wasiat wajibah; Surat kuasa khusus yang tidak memenuhi syarat yang ditentukan Undang-Undang karena cap jempol yang dibubuhkan pada surat kuasa oleh pemberi kuasa yang buta huruf tidak dilakukan di hadapan pejabat camat/notaris/hakim, maka surat kuasa yang demikian itu masih dapat diterima oleh hakim, karena pemberi kuasa tersebut telah ikut hadir dalam persidangan pengadilan agama, bersama dengan penerima kuasa.

Yurisprudensi merupakan salah satu sumber-sumber hukum yang berlaku. Yurisprudensi adalah putusan-putusan hakim atau pengadilan yang telah berkekuatan hukum tetap dan dibenarkan oleh Mahkamah Agung (MA) sebagai pengadilan tingkat kasasi atau putusan Mahkamah Agung sendiri yang sudah berkekuatan hukum tetap. Sehingga, untuk kepentingan penyusunan disertasi ini, peneliti menggunakan pendekatan penelitian secara normatif dan empirik yang didukung dengan studi kepustakaan.

${ }^{13} \mathrm{C}$. Van Vollenhoven, Miskeningen Van Het Adatrecht Boekandel en Drukkerij Voorkeem van Nederlandsch-Indie (Leiden: E.J. Brill. 1931), jilid II, hlm. 61.

${ }^{14}$ Ahmad Kamil, et al., Hukum Perlindungan dan Pengangkatan Anak di Indonesia (Jakarta: Rajawali Pers. 2010), cet. II, hlm. 20. 
Kaitannya dengan yurisprudensi mengenai anak angkat menurut hukum Adat, maka pemberlakuannya hampir sama dengan ahli waris pengganti tersebut di atas, yaitu sejak adanya pengakuan hukum Adat oleh Pemerintah Kolonial Hindia Belanda, yang mana Yurisprudensi Pengadilan Negeri dan Mahkamah Agung tentang anak angkat, misalnya terdapat dalam Putusan Nomor: 416 K/SIP1968, tanggal 04 Januari 1969, Nomor 679 K/SIP/1968, tanggal 24 Desember 1969, dan Nomor 102 K/SIP/1972, tanggal 23 Juli 1973, bahwa kedudukan anak angkat terhadap warisan orangtua angkat sama dengan kedudukan anak kandung.

\section{Akibat Hukum Pemberian Harta Waris Kepada Anak Angkat}

Sebelumnya Allah SWT menegaskan permasalahan anak angkat kepada Rasulullah SAW, beliau diperintahkan agar berpaling dari kaum musyrikin, tidak menghiraukan gangguan mereka sambil menantikan putusan Allah. Hal tersebut disampaikan setelah menyatakan bahwa Al-Quran adalah wahyu Ilahi yang bersumber dari Tuhan pemilik semesta alam, dan agar beliau konsisten, tidak meragukan wahyu Allah. Bertakwalah kepada Allah, tidak patuh kepada ajakan kaum kafir dan munafik, serta mengikuti secara sungguh-sungguh wahyu yang diturunkan Allah itu. ${ }^{15}$ Kemudian Allah menurunkan hukum yang tegas tentang anak angkat yang sudah dikenal di kalangan bangsa Arab Jahiliyah, dengan sebutan "al-tabanni". Al-tabanni sama dengan adopsi, dan anak yang diadopsi diperlakukan persis sama dengan anak kandung.

Ketegasan hukum anak angkat dalam Islam atas dasar ayat al-Quran, berupa 'larangan' memberlakukan anak angkat seperti anak kandung dilihat dari sudut pandang teori kedaulatan Tuhan, dalam al-Quran dimuat beberapa ayat yang memerintahkan orang Islam untuk taat kepada Allah dan RasulNya, ${ }^{16}$ tidak dibenarkan untuk mengambil pi-

${ }^{15}$ M. Quraish Shihab, Tafsir al-Mishbah (Jakarta: Lentera Hati. 2002), vol. 11, hlm. 215-216.

${ }^{16}$ Q.S. Al-Nisâ: 59, Q.S. Al-Nûr: 51, Q.S. Al-Hasyr: 7, Q.S. Al-Nisâ: 80. lihan lain kalau ternyata Allah dan Rasul-Nya telah menetapkan hukum yang pasti dan jelas, ${ }^{17}$ mengambil pilihan hukum lain di mana Allah dan Rasul-Nya telah memberikan ketentuan hukum dianggap zhalim, kafir, atau fasiq, ${ }^{18}$ tanyakan pada hati nuranimu, apakah tidak termasuk umat Muhammad yang melecehkan al-Quran. ${ }^{19}$

Ayat yang menghapuskan kedudukan anak angkat seperti anak sendiri dinyatakan dalam QS al-Ahzab ayat 4-5 yang berbunyi:

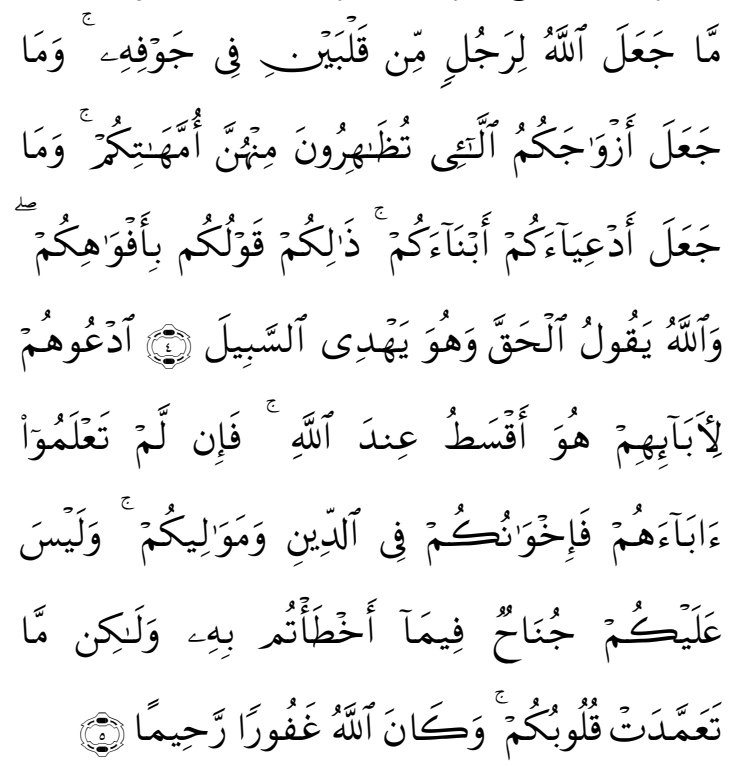

Allah sekali-kali tidak menjadikan bagi seseorang dua buah hati dalam rongganya; dan dia tidak menjadikan istri-istrimu yang kamu zhihar itu sebagai ibumu, dan dia tidak menjadikan anak-anak angkatmu sebagai anak kandungmu (sendiri). yang demikian itu hanyalah perkataanmu dimulutmu saja. dan Allah mengatakan yang sebenarnya dan dia menunjukkan jalan (yang benar) (4); Panggilah mereka (anak-anak angkat itu) dengan (memakai) nama bapak-bapak mereka; Itulah yang lebih adil pada sisi Allah, dan jika kamu tidak mengetahui bapak-bapak mereka, maka (panggilah mereka sebagai) saudarasaudaramu seagama dan maula-maulamu. Dan tidak ada dosa atasmu terhadap apa yang kamu khilaf padanya, tetapi (yang ada dosanya) apa yang disengaja oleh hatimu. Dan

\footnotetext{
${ }^{17}$ Q.S. Al-Ahzab: 36, Q.S. Ali-Imrân: 32, Q.S. Al-Nûr: 47 dan 48.

${ }^{18}$ Q.S. Al-Ma'idah: 44, 45, dan 47.

${ }^{19}$ Q.S. Al-Furqan: 30.
} 
adalah Allah Maha Pengampun lagi Maha Penyayang (5).

Ayat tersebut turun berkenaan dengan kasus Zayd ibn Haritsah yang diadopsi oleh Nabi Muhammad SAW, Zayd yang meninggalkan ayahnya dan dipelihara oleh kakeknya, satu ketika diculik oleh segerombolan berkuda dari suku Tihamah. Anak muda itu dibawa ke Mekkah dan dibeli oleh Hakim ibn Hizam Ibn Khuwailid yang memberikannya kepada saudara perempuan ayahnya yakni Khadijah binti Khuwailid. Wanita mulia yang kemudian menjadi istri Nabi SAW. itu, menghadiahkan Zayd kepada Nabi SAW., Zayd tinggal bersama beliau sekian lama. Di samping itu, usaha pencarian oleh kakeknya berhasil mengetahui bahwa Zayd berada di Mekah, maka mereka menemui Nabi SAW. dan bersedia membayar tebusan bila beliau mengizinkan Zayd r.a. kembali kepada keluarganya. Nabi Muhammad SAW. Menawarkan kepada mereka jalan yang lebih baik, yakni beliau bersedia mengizinkan Zayd kembali kepada keluarganya tanpa tebusan bila itu yang menjadi pilihan Zayd, tetapi di sisi lain para keluarga diminta untuk membiarkan Zayd tetap bersama Beliau, bila itu yang menjadi pilihan Zayd. Tawaran yang sangat simpatik ini diterima semua pihak. Ternyata Zayd r.a. enggan bergabung dengan keluarganya dan memilih hidup bersama Nabi SAW. Nah, ketika itulah Beliau mengumumkan kepada masyarakat Mekkah, bahwa Zayd adalah putra beliau, dan sejak itu pula ia dikenal dengan nama Zayd ibn Muhammad. $^{20}$

Ayat di atas, membatalkan adopsi Nabi itu, dan semua adopsi yang dilakukan masyarakat muslim. Dengan turunnya ayat ini, Nabi Muhammad SAW. memperingatkan kepada semua orang agar tidak mengaku Mempunyai garis keturunan dengan satu pihak padahal hakikatnya tidak demikian. Hal demikian dinyatakan dalam sabda Nabi Muhammad SAW. yang berbunyi:

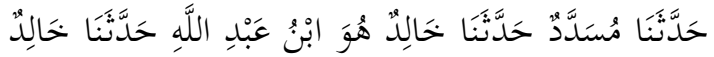

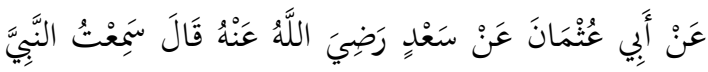

${ }^{20} \mathrm{Ibid}$. hlm. 221-222.

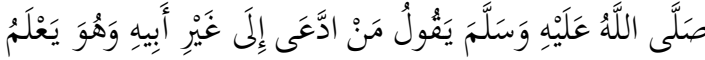

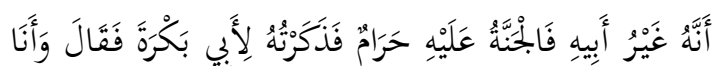

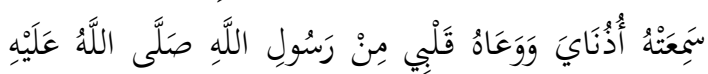

$$
\begin{aligned}
& 21 \text { وَسَلَّمَ }
\end{aligned}
$$

Musaddad dan Khalid bin 'Abdullah telah menyampaikan hadits kepada kami demikian juga Khalid bin Utsman menyampaikan hadits kepada kami yang diterima dari bapaknya (Utsman) yang berasal dari Sa`ad, beliau berkata : Saya mendengar Rasulullah SAW.. Bersabda "Seseorang yang menisbahkan dirinya kepada laki-laki yang bukan orang tuanya haram baginya mencium bau surga", kemudian hadits ini saya ceritakan kepada Abu Bakar, beliau berkata 'saya mendengar sendiri hadits tersebut dari Rasulullah dan saya simpan dalam hati'.

Pengakuan anak angkat seperti anak kandung sendiri adalah kebiasaan pada masyarakat Jahiliyah dan dengan turunnya ayat Allah di atas maka dalam Islam hal tersebut telah dihapus, sebagaimana petikan di bawah ini:

$$
\begin{aligned}
& \text { أدعياءكم: جمع دعي, و هو الذى يدعى ابنا و ليس بابن, }
\end{aligned}
$$

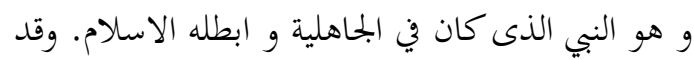

$$
\begin{aligned}
& \text { تبنّى عليه السلام (زيد بن حارثة) قبل النبوة احكمة جلياة } \\
& \text { نبينها بعد ان شاء الله. } 22
\end{aligned}
$$

Kalimat ad'iyâ 'ukum jamak dari kalimat da'â, digunakan untuk memanggil anak kepada yang bukan anak. Kalimat itu digunakan sebagai cara pengangkatan anak (adopsi) pada masa jahiliyah yang telah dibatalkan oleh Islam. Nabi SAW. pernah mengadopsi Zayd bin Haritsah di masa jahiliyah sebelum beliau menjadi Nabi karena suatu tujuan yang akan kami sebutkan, insya Alllah.

\footnotetext{
${ }^{21}$ Bukhari, Kutub al-Tis'ah Shahih Bukhari, 6269 "Siapa yang mengakui seseorang yang bukan bapaknya sebagai bapaknya, maka surga haram baginya".

${ }^{22}$ Muhammad Ali al-Shâbûny, Shafwah al-Tafâsir, Tafsir li Al-Quran al-Karîm (Beirut: Dâr al-Kutub alIslamiyyah. 2002), vol. 2, hlm. 249. Baca juga Quraish Shihab, Tafsir al-Misbah. vol. 11, hlm. 222.
} 
Ulama kontemporer seperti Yusuf alQardhawi berpandangan bahwa mengangkat anak dan menisbahkan nasab pada bapak angkat adalah haram. Apalagi apabila pembagian warisan bagi anak angkat disamakan dengan anak sendiri. ${ }^{23}$ Maksudnya adalah mengaku-ngaku bapak yang bukan bapaknya. Sedangkan memelihara anak orang lain atau anak yatim tentu saja perbuatan mulia, namun memposisikan anak angkat menjadi ahli waris adalah suatu hal yang bertentangan dengan ketentuan nash.

Seluruh ulama tafsir dan ulama fikih sependapat bahwa anak angkat dibolehkan sebatas pemeliharaan, pengayoman, dan pendidikan, kecuali dilarang memberi status sebagai layaknya anak kandung. Sedangkan dalam konteks Indonesia, pengaruh hukum Adat lebih kental, yakni meskipun masyarakat mayoritas beragama Islam, tetapi dalam masalah anak angkat kebanyakan lebih memilih adat dengan meninggalkan ketentuan nash-nash syara' di atas.

Dalam praktiknya anak angkat di Indonesia sama dengan masyarakat jahiliyah Arab, diperlakukan sebagai anak sendiri. Dan dengan dalih si anak banyak berjasa memelihara orang tua angkatnya, maka yang dipakai adalah fiksi hukum tersebut, kemudian diberi porsi wasiat wajibah dari harta warisan. Sebaliknya dalam putusan-putusan pengadilan negeri, anak angkat sama dengan anak sendiri, atas dasar hukum Adat; sekalipun semua pihak beragama Islam. Dalam hal ini telah terjadi "titik singgung" yang berkepanjangan dalam menyelesaikan sengketa harta warisan bagi anak angkat antara Pengadilan Negeri dan Pengadilan Agama. ${ }^{24}$

\footnotetext{
${ }^{23}$ Yusuf al-Qaradhawi, al Halâl Wal Harâm fil Islam (Beirut: al Maktab al Islami. 1994), hlm. 206-209.

${ }^{24}$ Peneliti telah mengusulkan kepada Ketua Mahkamah Agung RI, agar pewaris dijadikan patokan dalam penyelesaian sengketa kewarisan (termasuk wasiat wajibah untuk anak angkat). Bila pewaris beragama Islam, penyelesaian sengketa kewarisannya ke pengadilan agama, pewaris nonmuslim ke pengadilan negeri. Dalam Rapat 'coffee morning' di Diklat MA Mega Mendung, Bogor, Jumat, tanggal 25 Juni 2010. Usul tersebut telah diterima baik dan segera akan diterbitkan Surat Edaran Mahkamah Agung (SEMA). Wait and See.
}

Dalam fiqih Islam, wasiat wajibah umumnya lebih didasarkan kepada pemikiran akal, yang di satu sisi dimaksudkan untuk memberikan rasa keadilan kepada orangorang yang dekat dengan pewaris, tetapi secara syar'i tidak memperoleh bagian dari jalur farâ'idh. Namun di sisi yang lain, keempat imam mazhab mengharamkannya jika hal itu akan memberikan madharat bagi ahli waris.

Mengacu kepada nash-nash dan tafsir di atas dikaitkan dengan ketentuan Pasal 209 $\mathrm{KHI}$, sesuai dengan teori mashlahah al-ummah, maka anak angkat dapat memperoleh bagian sebagai wasiat wajibah dari harta warisan dengan rekonstruksi pemikiran hukum Islam sebagai berikut:

1. Bahwa dalam Islam, anak angkat "dibolehkan" sebatas pemeliharaan, pengayoman, dan pendidikan; dan 'dilarang' memberi status sebagai layaknya anak kandung. Kalimat ini hendaklah dimuat dalam pertimbangan hukum, setiap putusan/penetapan pengangkatan anak oleh pengadilan agama;

2. Bahwa anak angkat dapat memperoleh harta dari orang tua angkatnya berdasarkan wasiat yang besarnya tidak boleh melebihi $1 / 3$ (sepertiga) harta orang tua angkatnya yang telah meninggal dunia, bila orang tua angkatnya tidak meninggalkan wasiat ia dapat diberi berdasarkan wasiat wajibah;

3. Bahwa pemberian wasiat wajibah tidak boleh merugikan hak-hak dari ahli waris: ${ }^{25}$

$$
\text { يضارّبه الورثة لحديث الأضرار بالورثة: يحرم أن يقف الشخص "لا ضرر و لا ضرار في }
$$

Haramnya merugikan ahli waris: seseorang diharamkan untuk memberikan wakaf yang dapat merugikan ahli waris, sebagaimana sabda Rasulullah SAW: Islam tidak memadharatkan dan dimadharatkan.

\footnotetext{
${ }^{25}$ Sayyid Sâbiq, Fiqh al-Sunnah (Beirut: Dâr al-Fikr. 1991), vol. III, hlm. 983.
} 
a. Besarnya wasiat wajibah tersebut tidak boleh melebihi bagian ahli waris. Bila harta orang tua angkat hanya sedikit, belum memadai untuk mensejahterakan ahli warisnya, maka tidak ada wasiat wajibah untuk anak angkat; memaksakan wasiat atau wasiat wajibah kepada anak angkat yang telah dilarang oleh Allah SWT memperlakukan sebagai anak sendiri, sama saja dengan menentang hukum Allah;

b. Bahwa bila ada sengketa tentang status anak angkat, harus dibuktikan dengan adanya putusan pengadilan;

c. Bahwa bila ada sengketa tentang wasiat atau wasiat wajibah bagi anak angkat, maka harus ada putusan pengadilan yang menyatakan: anak angkat tersebut berhak atau tidak berhak atas wasiat atau wasiat wajibah - dalam praktek dikumulasi dengan sengketa kewarisan, tetapi petitum khusus untuk dinyatakan berhak mendapat wasiat wajibah tidak ada, karena ketentuan dalam KHI bersifat imperatif, harusnya bersyarat; merujuk kepada nash al-Quran yang mensyaratkan pewaris meninggalkan harta yang banyak; demikian ulama tafsir telah menafsirkan kata khairan QS. [2]: 180.

Kemudian dalam diskursus fiqih Islam sendiri, masalah wasiat wajibah umumnya lebih didasarkan kepada pemikiran akal, yang di satu sisi dimaksudkan untuk memberikan rasa keadilan kepada orang-orang yang dekat dengan pewaris, tetapi secara syar'i tidak memperoleh bagian dari jalur faraidh. Namun di sisi yang lain, keempat imam mazhab mengharamkannya jika hal itu akan memberikan madharat bagi ahli waris.

Berdasarkan uraian di atas, maka penulis dapat merumuskan bahwa pemberian harta warisan kepada anak angkat dengan menggunakan konsep wasiat wajibah ke dalam KHI, pada umumnya bukan didasarkan kepada landasan syari'at (qath'iy al-dilâlah), tetapi lebih didasarkan kepada logika hukum dan pertimbangan kemanusiaan ahli waris untuk memberikan sebagian harta waris kepada saudara atau anak angkat, meski secara syar'i hal tersebut termasuk zhanniy al-di- lâlah. Sehingga memberian harta waris sebesar $1 / 3$ dari harta waris kepada anak angkat dengan menyandarkan hukum kepada wasiat wajibah, merupakan ijtihad yang keliru, bertentangan dengan nash, dan dapat merugikan ahli waris utama.

\section{E. Penutup}

Pada bagian penutup ini penulis menggarisbawahi pokok pikiran terkait dengan 2 (dua) bentuk pengangkatan anak yang dipahami dalam perspektif hukum Islam, yaitu: pertama, bentuk pengangkatan anak (tabanni) yang dilarang sebagaimana tabanni yang dipraktikkan oleh masyarakat Jahiliyah dan hukum perdata sekuler, yang menjadikan anak angkat sebagai anak kandung, dengan segala hak-hak sebagai anak kandung, dan memutuskan hubungan hukum dengan orang tua asalnya, kemudian menisbahkan ayah kandungnya kepada ayah angkatnya; dan kedua, pengangkatan anak (tabanni) yang dianjurkan yaitu pengangkatan anak yang didorong oleh motivasi beribadah kepada Allah SWT dengan menanggung nafkah sehari-hari, biaya pendidikan, pemeliharaan, dan lain-lain tanpa harus memutuskan hubungan hukum dengan orang tua kandungnya, tidak menasabkan dengan orang tua angkatnya, tidak menjadikannya sebagai anak kandung sendiri, dengan segala hakhaknya.

Selain itu, peneliti juga merumuskan kesimpulan sebagai berikut: pertama, memposisikan anak angkat sebagai penerima waris (seperti anak kandung) dalam hukum Islam tidak dibenarkan, karena bertentangan dengan nash dan dapat mencederai hubungan kekerabatan di kalangan keluarga; kedua, pemberian waris kepada anak angkat menurut wasiat wajibah dalam $\mathrm{KHI}$ hanya didasarkan pada pertimbangan adat dan kemanusiaan bagi pemenuhan hak waris bagi anak angkat;' ketiga, pemberian harta warisan kepada anak angkat sebagaimana diatur dalam Pasal $209 \mathrm{KHI}$ diberikan menggunakan pertimbangan wasiat wajibah sebanyak-banyaknya $1 / 3$ dari harta warisan ahli waris utama perlu dikaji ulang, karena bertentangan dengan nash-nash syari'at (qath'iyy al-dilalah); dan keempat, ketentuan hukum pemberian 
harta warisan kepada anak angkat yang diatur dalam Pasal 209 KHI merupakan fakta yuridis masuknya pengaruh hukum Adat dan hukum Barat ke dalam KHI.

\section{Daftar Pustaka}

Ali, Muhammad Daud. 1991. Hukum Islam: Pengadilan Agama dan Masalahnya. Bandung: Rosdakarya.

Hanafi, A. 1987. Teologi Islam. Jakarta: Pustaka Al-Husna.

Ichtiyanto. 1991. Pengembangan Teori Berlakunya Hukum Islam di Indonesia. Bandung: Rosda Karya.

Idris, Taufiq. 1980. Aliran-aliran Populer dalam Teologi Islam. Surabaya: Bina Ilmu.

Kamil, Ahmad et al. 2010. Hukum Perlindungan dan Pengangkatan Anak di Indonesia. Jakarta: Rajawali Pers.
Qaradhawî, Yusuf, al-. 1994. al Halâl Wal Haram fil Islâm. Beirut: al Maktab al Islâmi.

Sâbiq, Sayid. 1991. Fiqh al-Sunnah. Beirut: Dâr al-Fikr.

Shabûny, Muhammad Ali, ash-. 2002. Shafwah al-Tafâsir, Tafsir li Al-Quran al-Karim. Beirut: Daar al-Kutub al-Islamiyyah.

Suminto, Aqib. 1985. Politik Islam Hindia Belanda. Jakarta: LP3ES.

Syafe'i, Rachmat. 2007. Ilmu Ushûl Fiqih Untuk UIN, STAIN, PTAIS. Bandung: Pustaka Setia.

Syâthibi, al-. t.th. al-Muawafaqat fi Ushûl alsyari'ah. Beirut: Dar al-Kutub al-Ilmiyyah.

Vollenhoven, C. Van. 1931. Miskeningen Van Het Adatrecht Boekandel en Drukkerij Voorkeem van Nederlandsch-Indie. Leiden: E.J. Brill. 1931. 